6. Tereshchuk A. D. Psihologichna dopomoga dityam z porushennyami emocijnoï sferi / A. D. Tereshchuk // Zbirnik naukovih prac' In-tu psihologiï im. G. S. Kostyuka NAPN Ukraïni. Problemi zagal'noï ta pedagogichnoï psihologiï. - 2012. - T. 24, ch. 5. - S. 217-229.

7. Shevchenko S. G. Diagnostika i korrekcija zaderzhki psihicheskogo razvitija u detej : posob. dlja uchitelej i specialistov korrekcionno-razvivajushhego obuchenija / S. G. Shevchenko, N. N. Malofeev, A. O. Drobinskaja i dr. ; pod red. S. G. Shevchenko. - M. : ARKTI, 2001. - 224 s.

M. A. Kots, T. M. Yatchuk. FEATURES OF PSYCHOLOGICAL CORRECTION OF THE EMOTIONAL-VOLITIONAL SPHERE OF CHILDREN OF PRIMARY SCHOOL AGE WITH SPECIAL EDUCATIONAL NEEDS.

The article analyzes the peculiarities of conducting remedial classes with children of primary school age with special educational needs. The advantages and disadvantages of corrective programs and the specifics of the selection of exercises for this category of children. It is determined that violations of the emotional and volitional sphere is one of the most difficult and least researched problems in psychology.

It is stated that the organization of remedial classes is one of the important issues for psychologists and teachers. The correct and timely inclusion of the child in such work will allow her to develop certain personal structures, to open compensatory opportunities and change her idea as a person. It is correction classes that will help children with special educational needs to believe in themselves and find their place in the social environment, learn how to establish healthy social contacts, and adequately assess their opportunities and shortcomings.

It is revealed that students with special educational needs have certain difficulties in owning their own emotions and including the volitional regulation of activity. Also, there is a lack of sufficient knowledge about human emotions, as well as ways to Express them.

It is proved that psychological intervention work is based not on the characteristics of the institution and on the individual characteristics of the children who regardless of the system of education must obtain all necessary remedial and developmental measures aimed at its adaptation to the social environment.

Keywords: primary school age, correctional work, special educational needs.

УДК 316.614:316.334.55/.5

\title{
ПСИХОЛОГІЧНІ ВІДМІННОСТІ В САМОРЕАЛІЗАЦІї ПІДЛІТКІВ МІСТА ТА СЕЛА
}

У статті здійснено аналіз процесу самореалізаџї особистості. Визначено, щуо розвиток наукового розуміння изього феномену належить представникам екзистенційногуманістичного напряму. Констатовано, щзо з підліткового віку особистість психологічно готова до повноиінної самореалізаиії себе в суспільстві.

Емпірично встановлено, що сочіалізачія дітей в місті, а ніж у селі, більшою мірою сприяє їх самореалізації в суспільстві.

Ключові слова: самореалізаџія, гуманістична школа, підлітковий вік, сочіалізація.

В статье осуществлен анализ процесса самореализации личности. Определено, что развитие научного понимания этого феномена принадлежит представителям экзистенциально-гуманистического направления. Констатировано, что с подросткового возраста личность психологически готова к полноценной самореализации себя в обществе.

Эмпирически установлено, что социализация детей в городе в большей степени, нежели в деревне, способствует их самореализачии в обществе.

Ключевые слова: самореализация, гуманистическая школа, подростковый возраст, сочииализачия.

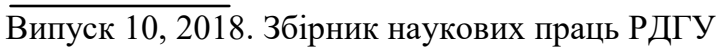


Постановка проблеми. Психологічний претекст звертання до емпіричного аналізу феномену самореалізації дітей підліткового віку в нинішньому суспільстві має сенс і він змістотворчий з огляду на ті соціальні зміни, які робляться дійсністю у нових демократичних умовах. Проблема самореалізації особистості у зазначений нами період життя сприймається актуальною і 3 тих причин, що в цей віковий етап дослідниками зауважуються відчутні психологічні зміни: розвивається готовність до функціонування в дорослому світі, що, в свою чергу, формує прагнення застосувати свої можливості, проявляти себе, загострює потребу в самовизначенні.

Аналіз останніх досліджень і публікацій. Сучасним дослідженням феномену самореалізації властивим є вивчення цілісного процесу життєвизначення людини (К. Абульханова-Славська, Л. Анциферова, Б. Богоявленська, Л. Мова, Т. Титаренко та ін.), виокремлення складових, механізмів, зв'язків особистісної самореалізації із віковою i гендерною динамікою змін (Є. Вахромов, В. Гупаловська, Л. Долинська, Н. Ісаєва, С. Кудінов, М. Мушкевич та ін.), а також вивчення мотивів, які забезпечують ефективну професійну самореалізацію особистості (3. Карпенко, 3. Крижановська [3], Я. Коломінський, Н. Кузьміна, М. Муртазаєва, М. Чобітько, Т. Щербан та ін.).

Формулювання цілей статті: здійснене теоретико-емпіричне дослідження має на меті проаналізувати феномен самореалізації особистості та виокремити психологічні відмінності самореалізації дітей підліткового віку, які мешкають в місті та селі.

Виклад основного матеріалу дослідження. Багатогранність феномену самореалізації особистості почала всебічно вивчатися психологією 3 розвитком екзистенційногуманістичного напряму (А. Маслоу, Р. Мей, Г. Олпорт, К. Роджерс, В. Франкл, Е. Фром, Е Шостром [4] та ін.). Попри сучасний інтерес науковців до зазначеного феномену, недостатньо вивченим залишається питання самореалізації підлітків, що сформувало наш науковий інтерес до нього. Аналіз наукової літератури з проблем самореалізації особистості підлітка засвідчує, що є найрізноманітніші підходи до трактування цього поняття. На думку вчених процес самореалізації стає можливим в $14-15$ років. В цей період розвивається можливість до функціонування в дорослому світі. Саме це породжує прагнення застосувати свої можливості, проявити себе, загострює потребу в самовизначенні.

Дослідники підкреслюють (І.С. Булах [1], Л. П. Василенко, Л. С. Виготський, М. В. Савчин та ін.), що саме в підлітковому віці впродовж незначного часу відбуваються інтенсивні та глибокі особистісні зміни, які призводять до формування потреби зростання, розвитку, самовдосконалення. Саме система взаємин із соціальним середовищем $\epsilon$ визначальною в спрямованості психічного розвитку підлітка. Своєрідність розвитку підлітка полягає ще й у тому, що він входить у нову систему взаємин і спілкування 3 дорослими і товаришами, займаючи серед них нове місце, виконуючи нові функції, які найчастіше зумовлені соціальним середовищем (Н.В.Корчакова [2]). Формування такого комплексу потреб підлітка стає основою його подальшої самореалізації в суспільстві.

Аналіз основних результатів емпіричного дослідження. Теоретичне обгрунтування проблеми дало змогу розробити програму фіксації, аналізу й оцінки характеристик самореалізації дітей підліткового віку. Відтак, експериментальною базою та контингентом дослідження виступили учні $8-10$ класів Луцького навчально-виховного комплексу загальноосвітньої школи I - III ступенів № 22 - ліцей Луцької міської ради Волинської області та Березовичівської загальноосвітній школи I - III ступенів Володимир-Волинського району Волинської області. Чисельність досліджуваних становила 117 осіб. Вік досліджуваних знаходився в межах від 14-ти до 15-ти років. За статевою ознакою - це гетерогенна вибірка.

Для досягнення мети наукового дослідження контингент досліджуваних, на основі місця проживання, був поділений на дві групи: група 1 (57 підлітків) - міські жителі, група 2 (60 підлітків) - діти сільської місцевості. Аналіз емпіричних даних здійснювався за встановленим критерієм. Дослідження проводилось в груповій формі. Методичним забезпеченням дослідження став опитувальник POI Е. Шострома. В його основі лежать ідеї самоактуалізації А. Маслоу та інших теоретиків екзистенційно-гуманістичного напрямку в 
психології. Діагностовані характеристики опитувальника POI Е. Шострома поділені на систему блоків, які проаналізуємо нижче. Перший блок включає в себе дві характеристики: “Компетентність у часі” та "Самопідтримку”, які сукупно утворюють блок базових шкал. Як засвідчують результати, за шкалою “Компетентності у часі” у двох досліджуваних груп виявлено середні показники (65\% та 40\% досліджуваних відповідно). Це може свідчити, що підлітки здатні цілісно сприймати минуле, теперішнє і майбутнє (переживають поточний момент свого життя у всій його повноті, а не просто як фатальний наслідок минулого або підготовку до майбутнього “справжнього” життя). За шкалою “Підтримки” у наших досліджуваних також виявлений середній показник (65\% та 40\% досліджуваних відповідно). Це свідчить, що діти підліткового віку демонструють незалежність у своїх вчинках, здатність приймати рішення, керуватися власними прагненнями й думками, цілями, переконаннями, установками і принципами. Це є ознакою вільності у виборі, незалежності від зовнішнього впливу. Наступні шкали утворюють блок додаткових шкал, які також поділені на блоки. На відміну від базових, які вимірюють осоновні характеристики самоактуалізації, додаткові шкали орієнтовані на реєстрацію окремих іï аспектів. Для додаткових шкал високий бал характеризує високу міру самоактуалізації досліджуваних.

Блок иінностей включає в себе такі шкали, як: "Ціннісні орієнтації" та "Гнучкості поведінки". За шкалою “Ціннісних орієнтащій” у досліджуваних двох груп виявлений середній показник (58,3\% підлітків групи 1 та 55\% підлітків групи 2), який свідчить про те, що діти сповідують такі цінності які властиві самоактуалізованій особистості. Тобто, наші досліджувані схильні керуватися лише власними цілями й цінностями; здатні легко змінювати свій стиль і тактику поведінки, зможуть швидко й адекватно реагувати на мінливу ситуацію; відкриті до нового досвіду; надають превагу новому та невідомому; в цілому позитивно орієнтовані на зовнішній світ. Показник за шкалою “Гнучкість поведінки" характеризується середнім рівнем вираження також у двох групах (41,6\% та 61,6\% досліджуваних відповідно). Ця ознака виявляється в гнучкості людини в реалізації своїх цінностей, в поведінці, взаємодії з оточуючими людьми, здатністю швидко й адекватно реагувати на мінливу ситуацію.

Блок почуттів включає в себе характеристики за такими шкалами як: шкала “Сензитивності” та шкала "Спонтанності”. За шкалою “Сензитивності” виявлено, що для 65\% підлітків, які проживають в місті характерний середній рівень вираження ознаки, а підлітки, які проживають в селі, (38,3\%) демонструють низький, а 36,6\% - середній рівень вираження ознаки. Ця шкала дає змогу виявити міру усвідомлення особистістю власних потреб і почуттів, можливість їх рефлексії. Тому, отримані бали можуть слугувати підставою для висновку про те, що діти міської місцевості демонструють краще розуміння власних відчуттів та думок, здатність їх структурувати та виражати. За шкалою "Спонтанності" виявлено, що для 46,6\% міських дітей характерний середній рівень за цією шкалою, а для $40 \%$ сільських підлітків - низький. Ця характеристика виявляє здатність особистості до спонтанного й безпосереднього вираження власних почуттів, до можливості вільного, автентичного, природного поводження себе з-поміж інших.

Наступний блок самоприйняття включає в себе такі шкали: “Самоповаги” та "Самоприйняття”. Як засвідчують результати, у підлітків першої групи, домінує середній рівень (56,6\%) за шкалою “Самоповаги” і низький (40\%) у другої. Результати за цією шкалою відображають здатність людини цінувати власні гідності, позитивні якості характеру, поважати себе за них. Результати дослідження за шкалою “Самоприйняття" відображають міру прийняття людиною себе такою, якою вона $\epsilon$, незалежно від оцінки своїх переваг, досягнень чи недоліків (можливо, і всупереч їм). Відтак, за цією шкалою найбільша чисельність досліджуваних групи 1 відображає середній рівень вираження ознаки (40\% опитаних), а досліджувані другої групи - низький (45\% опитаних). Це може слугувати основою для припущення про те, що особистість здатна до саморефлексії, проте $\epsilon$ труднощі 3 раціоналізацією власного "Я”.

За шкалою "Уявлення про природу людини” у дітей-міських жителів (група 1) переважає середній рівень вираження ознаки (66,6\% опитаних), а в дітей-сільських жителів - 
низький показник (45\% опитаних). Отримані результати досліджуваних виявили проблему в сприйманні підлітками двох груп природи людини, несформованість гуманістичної позиції щодо неї.

За шкалою “Синергіï” підлітки двох груп демонструють низькі показники: група 1 $35 \%$ дітей, а група - 45\% досліджуваних. Ці результати можуть свідчити про несформовану здатність опитаних до цілісного сприйняття світу та людей, до розуміння інтеграції протилежностей, таких як гра і робота, тілесне та духовне й інше.

Ще один блок додаткових шкал представлений шкалою “Прийняття агресіі” та “Контактності”. Результати за цим блоком розподілились таким чином: за шкалою "Прийняття агресії" у досліджуваних першої групи виявлено середній рівень - 50\% досліджуваних, а у другої - низький рівень (43,3\% досліджуваних). Ці результати свідчать про погану здатність молодої особи приймати своє роздратування, гнів і агресивність як природний прояв людської природи, про недостатню інтегрованість у власному “Я” його негативних, “тіньових" суб-я. За шкалою “Контактності” у досліджуваних першої групи виявлено середній показник (55\% досліджуваних), а у другої - низький показник (41,6\% досліджуваних). Як бачимо, менших проблем у встановленні міжособистісних взаємин маємо у дітей міста. Тобто, ці підлітки краще, а ніж діти сільських місцевостей встановлюють контакти 3 людьми. Ці результати узгоджуються 3 результатами за попередньою шкалою у дітей сільських місцевостей.

I, наостанок, нашого аналізу результатів методики POI Е. Шострома, проаналізуємо емпіричні дані за блоком відношення до пізнання, який включає в себе: шкалу "Пізнавальних потреб” та шкалу “Креативності”. За шкалою "Пізнавальних потреб” виявлено домінування середнього показника у дітей, які проживають в місті (48,3\% досліджуваних) і низький показник у дітей сільської місцевості (55\% досліджуваних). Шкала визначає міру вираженості у людини прагнення до набуття знань про навколишній світ. Це означає, що у наших досліджуваних недостатньою мірою розвинені пізнавальні потреби, діти не проявлять захоплення до набуття нових знань, не прагнуть до розвитку. За шкалою “Креативності” у дітей першої групи виявлено середній показник (61,6\% досліджуваних), а в дітей другої групи - низький $(45 \%$ досліджуваних). Ця шкала характеризує вираженість творчої спрямованості особистості і за результатами наших досліджуваних ми спостерігаємо, що молодь не надає особливого значення творчим пошуках у власному житті.

Висновки 3 даного дослідження і перспективи подальших розвідок. Отож, узагальнений аналіз результатів за опитувальником самоактуалізації POI Е Шострома демонструє домінування середніх показників за усіма шкалами методики у дітей, які проживають у місті, та, здебільшого, низькі показники у дітей сільської місцевості. Жодна із груп досліджуваних не демонструє у повній мірі характеристик самоактуалізованої особистості, що може слугувати підгрунтям для припущення про те, що в підлітковому віці лише починається повноцінне входження молодої людини в соціальний простір, що перешкоджає максимальному виповненню в цьому віці. Окрім того, процес самореалізації тісно пов'язаний з проходженням соціалізації особистості і в цьому аспекті ми можемо фіксувати кращі характеристики цього процесу в дітей міста, а ніж села.

Отримані нами результати, ясна річ, не вичерпують усіх аспектів цього багатогранного процесу і подальші пошуки в цьому напрямку стануть підгрунтям для нових досліджень.

\section{Список використаних джерел}

1. Булах І. С. Психологія особистісного зростання підлітків: реалії та перспективи / I. С. Булах. - Вінниця : Нілан-лтд, 2016. - 340 с.

2. Корчакова Н. В. Атрибуція просоціальних якостей як важлива лінія особистісного розвитку підлітків / Н. В. Корчакова // International scientific-practical conference «Theoretical and applied researches in the field of pedagogy, psychology and social science» (Kielce, Poland, December 28-29, 2016). - Kielce : Holly Cross University, 2016. - C. 255-259. 
3. Крижановська 3. Ю. Самореалізація особистості після виходу на пенсію, як спосіб ії самовиповнення / 3. Ю. Крижановська, О. О. Сичак // Психологія: реальність і перспективи : зб. наук. пр. Рівнен. держ. гуманіт. ун-ту. - 2016. - Вип. 7. - С. 106-109.

4. Шостром Э. Человек-манипулятор. Внутреннее путешествие от манипуляции к актуализации / Э. Шостром. - Москва, 2003. - 116 с.

\section{References}

1. Bulakh I. S. Psykholohiia osobystisnoho zrostannia pidlitkiv: realii ta perspektyvy / I. S. Bulakh. - Vinnytsia : Nilan-ltd, 2016. - 340 s.

2. Korchakova N. V. Atrybutsiia prosotsialnykh yakostei yak vazhlyva liniia osobystisnoho rozvytku pidlitkiv / N. V. Korchakova // International scientific-practical conference «Theoretical and applied researches in the field of pedagogy, psychology and social science» (Kielce, Poland, December 28-29, 2016). - Kielce : Holly Cross University, 2016. - C. 255-259.

3. Kryzhanovska Z. Yu. Samorealizatsiia osobystosti pislia vykhodu na pensiiu, yak sposib yii samovypovnennia / Z. Yu. Kryzhanovska, O. O. Sychak // Psykholohiia: realnist i perspektyvy : zb. nauk. pr. Rivnen. derzh. humanit. un-tu. - 2016. - Vyp. 7. - S. 106-109.

4. Shostrom Э. Chelovek-manypuliator. Vnutrennee puteshestvye ot manypuliatsyy $\mathrm{k}$ aktualyzatsyy / Э. Shostrom. - Moskva, 2003. - 116 s.

\section{Z. Kryzhanovska, T. Novosad. PSYCHOLOGICAL DIFFERENCES OF TEENAGERS SELF-REALIZATION IN THE CITY AND IN THE COUNTRYSIDE. \\ The article presents the analysis of the process of self-realization. It was determined that the development of scientific understanding of this phenomenon belongs to representatives of the existential-humanistic direction. It was found that adolescent personality psychologically ready for full of self-realization in society. Empirical evidence shows that the socialization of children in the city, rather than in the village, greatly contributes to their self-realization in society.}

Key words: self-realization, humanistic school, teenage age, socialization.

\section{КОМПЛЕКСНА ПСИХОЛОГО-ПЕДАГОГІЧНА РЕАБІЛІТАЦІЯ ДІТЕЙ 3 ОСОБЛИВИМИ ПОТРЕБАМИ ЗАСОБАМИ СЕНСОРНОЇ ІНТЕГРАЦЇ̈}

У статті розглядаються особливості проведення комплексної психолого-педагогічної реабілітації дітей з особливими потребами засобами сенсорної інтеграції. Висвітлено результати попередніх наукових досліджень, у яких обгрунтовано значення сенсорної інтеграчіі для розвитку дітей з психофізичними порушеннями. Сенсорна інтеграція пропонує нове розуміння причин поведінкових порушень дитини та ознайомлює з новими стратегіями підвищення концентрації уваги, мотивації та комунікації. Доведено, щуо комплексне поєднання психолого-педагогічних та медичних заходів у створенні єдиного збагаченого педагогічного середовища має синергетичний ефект - ефективність комплексного впливу значно перевищує сумарну ефективність тих самих заходів у випадку їх окремого застосування.

Ключові слова: комплексна психолого-педагогічна реабілітаџія, соціальна реабілітація, реабілітологія, сенсорна інформаџія, сенсорна активність, «сенсорна кімната», сенсорна корекиія, сенсорна інтеграція.

В статье рассматриваются особенности проведения комплексной психологопедагогической реабилитаџии детей с особыми потребностями средствами сенсорной интеграции. Представлены результаты предыдущих исследований, в которых обосновано значение сенсорной интеграции для развития детей с психофизическими нарушениями. 